\title{
LOS REPORTAJES FOTOGRÁFICOS EN LA PRENSA GRÁFICA COMO INSTRUMENTO DE PROPAGANDA Y DIVULGACIÓN DEL ESCULTISMO AL SUR DE BRASIL Y EN ESPAÑA EN LAS PRIMERAS DÉCADAS DEL SIGLO XX*
}

\author{
Reportage photography in the news press as a propaganda \\ and promotion tool of scouting in southern Brazil and Spain \\ in the early decades of the 20th century
}

\section{Maria Augusta Martiarena de Oliveira ${ }^{\varphi}$ y Bernat Sureda Garcia ${ }^{\omega}$}

Fecha de recepción: 13/06/2017 • Fecha de aceptación: 05/12/2017

Resumen. En este artículo se estudia el discurso propagandístico que la prensa ilustrada nos ofrece de los boy scouts en el sur del Brasil y en España en las primeras décadas del siglo xx. Para el estudio nos hemos basado en las fotografías publicadas en las revistas de la época. En el artículo se demuestra como mediante las fotografías, tanto en Brasil como en España, desde las instancias del poder, se ofrece una reinterpretación del método creado por el militar británico Robert Baden-Powell, con el objetivo de dar a los jóvenes formación patriótica mediante la disciplina y el orden inculcando sentimientos favorables al militarismo. La Primera Guerra mundial, la postguerra y la crisis social y económica de aquellos años crearon el contexto necesario para una exaltación patriótica que encontró en el método scout una forma de adoctrinamiento y de formación militarista de la juventud. Las imágenes publicadas de los grupos de boy scouts, que se organizan en

\footnotetext{
* Este artículo se ha realizado en el marco del proyecto La fotografía publicada como representación de los cambios y las continuidades en la cultura escolar (1900-1970), EDU2014-52498-C2-2-P, financiado en el Programa Estatal de Fomento de la Investigación Científica y Técnica de Excelencia, Subprograma Estatal de Generación de Conocimiento, en el marco del Plan Estatal de Investigación Científica y Técnica y de Innovación 2013-2016. Ministerio de Economía, Industria y Competitividad (AEI/FEDER, UE).

${ }^{\varphi}$ Instituto Federal de Educação, Ciência e Tecnologia do Rio Grande do Sul. Brasil. augusta.martiarena@osorio.ifrs.edu.br

${ }^{\oplus}$ Grup d'Estudis d'Història de l'Educació/ IRIE. Departament de Pedagogia i didàctiques especifiques. Facultat d'Educació. Universitat de les Illes Balears. Ctra. Valldemossa, Km. 7,5. 07122 Palma de Mallorca. España. bernat.sureda@uib.es
}

Cómo citar este artículo: Oliveira, Maria Augusta Martiarena de y Bernat Sureda Garcia. «Los reportajes fotográficos en la prensa gráfica como instrumento de propaganda y divulgación del escultismo al sur de Brasil y en España en las primeras décadas del siglo xx». Historia y Memoria de la Educación 8 (2018): 195-230. 
ambos países poco después de la creación del método en Inglaterra, muestran habitualmente su participación en actividades que implican subordinación al poder y rigurosa disciplina. Por el contrario, se encuentran pocas fotografías que muestren exclusivamente la vertiente lúdica y de educación activa que podía comportar la aplicación del método.

Palabras clave: Boy scouts; Fotografía; Revistas ilustradas; Propaganda; Nacionalismo

Abstract. This article looks at the propaganda-driven coverage of boy scouts in the illustrated press in southern Brazil and Spain in the early decades of the 20th century. We have used published photographs from magazines of the period for our study. The article shows how the institutions of power in Brazil and Spain used photographs to reinterpret the scout method created by the British soldier Robert Baden-Powell to provide young boys with patriotic training through discipline and order, instilling a positive disposition towards militarism. The First World War, the post-war period and the social and economic crisis of the time created the necessary backdrop for a patriotic zeal that found a way to indoctrinate and promote military training for young people through the scout method. The published images of boyscout troops, set up in both countries shortly after the creation of the movement in England, generally show them participating in activities that involve subordination to power and rigorous discipline. In contrast, there are few photographs that show exclusively the more fun, playful aspects of the method, or its use of active education

Keywords: Boy scouts; Photography; Illustrated magazines; Propaganda; Nationalism

\section{INTRODUCCIÓN}

Como es sabido, el escultismo fue creado por el militar inglés Robert Stephenson Smith Baden-Powell a partir de una primera experiencia de acampada con un grupo de jóvenes en la isla de Browsea en 1907. El método se dio a conocer con la publicación en 1908 de su libro Scouting for Boys y tuvo rápidamente una gran difusión internacional. Como ha indicado Eduard Vallory, diversos factores contribuyeron a esta divulgación:

Muy probablemente, son tres las claves del éxito del scouting. Primeramente, su oportunidad histórica. La propuesta aparece en la época en que en el mundo occidental nacen los conceptos de «juventud» y de «tiempo libre», y también cuando se elogia el campo y la vida natural en contraposición a la vida en la ciudad industrial. En segundo lugar, la amplísima complicidad del pro- 
yecto con las instituciones de autoridad social y política en Gran Bretaña, es decir, con la monarquía, el ejército, la escuela y la Iglesia, una complicidad que se reproducirá en otros muchos países. Y finalmente, la heterogeneidad y relativa ambigüedad de la propuesta de ciudadanía de Scouting for Boys, libro referente desde los inicios y que lo será durante toda su historia, una heterogeneidad que permite no sólo una amplia aceptación, sino también la posterior internacionalización de la propuesta. ${ }^{1}$

Realmente el método nace en un momento en que está madura la construcción social del concepto de «juventud». Como ha señalado Antonio Santoni, a finales del siglo XIX se produce una creciente toma de conciencia de identidad de los jóvenes relacionada con una mayor independencia de sus familias en el marco del desarrollo de la sociedad industrial y de la concentración urbana. Entre los jóvenes de las clases sociales con posibilidades económicas, se retrasa el paso de la infancia a la vida adulta y productiva a causa de una escolaridad más prolongada. ${ }^{2}$ A principios del siglo xx se observa el incremento de las agrupaciones de jóvenes en grupos y pandillas lo que facilita la construcción de una cultura juvenil como forma específica de concebir e interpretar la realidad y de manifestar el deseo de tener una mayor presencia e influencia social. ${ }^{3}$

La difusión del escultismo se vio también facilitada por la aparición del concepto de tiempo libre. A ello contribuyó también la ampliación de la escolarización y el incremento de la edad de asistencia a los centros de enseñanza. El incremento de la escolarización de los jóvenes establecía un calendario y unos ritmos horarios en los que quedaba tiempo libre. Al mismo tiempo, para los jóvenes trabajadores, las legislaciones laborales que se fueron aprobando introducían limitaciones en los horarios de trabajo. Incluso la encíclica Rerum Novarum de 1891, que impulsó el catolicismo social, reivindicaba una jornada laboral justa y un descanso dominical que pudiese servir para ocio, formación y cumplimiento de las obligaciones religiosas. Este tiempo libre se convertía en un espa-

\footnotetext{
${ }^{1}$ Eduard Vallory, L'escoltisme mundial (Barcelona: Proa/Institut d'Estudis Catalans, 2010), 23.

${ }^{2}$ Antonio Santoni Rugiu, «Moviments, associacionisme i educació juvenil entre el vuit-cents i els primers anys del nou-cents», Educació i Història: revista d'història de l'educació 6 (2003): 9-18.

${ }^{3}$ Michelle Perrot, «La juventud obrera. Del taller a la fábrica», en Historia de los jóvenes. II La Edad Contemporánea, editado por Giovanni Levi y Jean-Claude Schmitt (Madrid: Taurus, 1996), 119-125.
} 
cio atractivo para introducir nuevas formas de socialización y formación para este segmento de edad que cada vez tenía más identidad y presencia.

El escultismo da respuesta también a la creciente corriente de opinión que se difunde entre algunos intelectuales y jóvenes de clase alta que relacionan la decadencia moral con las consecuencias de la sociedad industrial madura. A finales del siglo XIX se extienden las críticas contra las consecuencias negativas de los procesos de urbanización y mecanización provocados por la revolución industrial. ${ }^{4}$ La percepción romántica de la naturaleza y la valoración positiva de las actividades en el campo, como alternativa a los efectos negativos de las ciudades, está en el trasfondo de las propuestas de Baden-Powell. ${ }^{5}$

El escultismo coincide igualmente con las ideas que impulsa el movimiento de la Escuela Nueva. María Montessori afirmó que el método creado por Baden-Powel era una continuación natural de la educación que ella propugnaba para los más pequeños. ${ }^{6}$ El creador del escultismo reconoció igualmente la relación de sus ideas con las de la educadora italiana. ${ }^{7}$ Igualmente Adolphe Ferrière (1879-1960), fundador del Bureau International des Écoles Nouvelles y uno de los máximos responsables de la divulgación en todo el mundo del movimiento renovador, declaró, en su obra L'École Active (1922), que el escultismo participaba plenamente de esta corriente pedagógica. ${ }^{8}$ Cabe recordar también la defensa que del escultismo hizo en Brasil la pedagoga progresista Elena Antipoff en su obra A escola e o escotismo. ${ }^{9}$

Este artículo es resultado de un estudio sobre las representaciones del escultismo en la prensa ilustrada en España y en Brasil. Las fuentes utilizadas para la investigación son, por lo tanto, las fotografías publicadas en la prensa durante las primeras décadas del siglo xx.

\footnotetext{
${ }^{4}$ Ángel C. Moreu Calvo, «Idealisme naturalista dels adolescents alemanys (1847-1945): dels Wandervögel (ocells errants) a la Hitlerjugeng (joventut hitleriana)», Educació i Història: revista d'història de l'educació 6 (2004): 36-43.

${ }^{5}$ Vallory, L'escoltisme mundial, 55.

${ }^{6}$ Marcel D. Forestier, Escoltisme, ruta de llibertat (Barcelona: Suc. de Joan Gilí, 1966), 38.

${ }^{7}$ Allen Warren, «Sir Robert Baden-Powell, the Scout Movement and Citizen Training in Great Britain, 1900-1920», The English Historical Review 101, no. 399 (1986): 376-398.

${ }^{8}$ Adolphe Emmanuel Ferrière, L'école active (Genéve: Edit. Du Forum, 1930), 87.

${ }^{9}$ Helena Antipoff, «A escola e o escotismo», Revista de Educação Física, Rio de Janeiro 25 (1935): 2-3.
} 
En el caso de Brasil, la opción fue utilizar tanto periódicos de circulación nacional como regional. Para la consulta de los periódicos nacionales, se buscó en las dos hemerotecas digitales más conocidas del país: Dominio Público y Archivo Digital de la Biblioteca Nacional. En esas hemerotecas digitales se encontraron ejemplares de las revistas que tenían circulación nacional en el periodo de investigación. Del listado de revistas, dos fueron las elegidas: Illustração Brazileira ${ }^{10}$ y Fon Fon. ${ }^{11}$ Seleccionadas las revistas ilustradas que servirían como fuentes de investigación, a través del estudio de cada una de las publicaciones, se buscaron fotografías de los scouts. La revista Illustração Brazileira fue la primera en publicar fotografías sobre el escultismo, pero el número en que fueron publicadas no está disponible en ninguna hemeroteca digital. La revista Fon-Fon contó con publicaciones de muchas fotografías de grupos de scouts en el año de 1922, en especial porque este fue el año del centenario de la independencia de Brasil en relación con Portugal. Para encontrar las imágenes, fueron estudiadas las publicaciones desde su creación hasta fines de los años veinte. En relación con los periódicos de circulación regional, la investigación fue realizada en el Archivo de Obras Raras de la Bibliotheca Pública Pelotense. En la provincia de Rio Grande do Sul las publicaciones no están digitalizadas, así que se tuvieron que consultar en el archivo. Por ese motivo fueron elegidos los siguientes periódicos para la investigación: Diario Popular, Almanach de Pelotas, y la revista Illustração Pelotense. ${ }^{12}$ En esta última no fueron encontrados registros. Tal y como sucedió con las revistas digitales, fue necesario realizar una búsqueda en cada una de las ediciones. En el caso de España se han consultado la Hemeroteca Digital de la Biblioteca Nacional de España, la Biblioteca Virtual de la Prensa Histórica, el Arxiu de Revistes Catalanes Antigues, la Hemeroteca de La Vanguardia y la del diario $A B C$, y especialmente su revista ilustrada Blanco y Negro. En estas bases de datos se han

\footnotetext{
${ }^{10}$ Entre las investigaciones que utilizan esta revista como fuente está la de Ana Luiza Martins, Revistas em revista: imprensa e práticas culturais em tempos de República, São Paulo (1890-1922) (São Paulo: Edusp - Editora da Universidade de São Paulo, 2001).

${ }^{11}$ Existen muchas investigaciones sobre esa revista, de las cuales podemos destacar: Maria Cecilia Zanon, «A sociedade carioca da Belle Époque nas páginas do nas páginas do Fon-Fon!», Patrimônio e Memória 4, no. 2 (2007): 217-235, y Vera Lins, «Em revistas, o simbolismo e a virada do século», en O moderno em revistas: representações do Rio de Janeiro de 1890 a 1930, ed. Cláudia de Oliveira (Rio de Janeiro: Garamond, 2010), 175-202.

${ }_{12}$ Sobre los periódicos pelotenses de las primeras décadas del siglo xx, se puede consultar Beatriz Ana Loner, «Jornais pelotenses diários na República Velha», Ecos Revista 2, no.1 (1998): 5-34.
} 
encontrado 28 publicaciones periódicas que incluyen fotografías relacionadas con los scouts entre 1909 y el principio de la II República en 1931.

\section{LOS ORÍGENES DE LOS SCOUTS EN ESPAÑA}

Como ha indicado María del Mar del Pozo, ${ }^{13}$ la difusión del escultismo en España está muy relacionada con la construcción de los nacionalismos. En el año 1912 el capitán de caballería Teodoro Iradier y el publicista Arturo Cuyàs, siguiendo el modelo del escultismo francés de los Eclaireurs de France, crearon los Exploradores de España. Aunque la finalidad de sus creadores no era la de constituir una asociación militar, fueron asociados a un nacionalismo español de carácter conservador que daba apoyo a un patriotismo imperialista. Como se ha indicado, la ambigüedad de los principios propuestos por Baden-Powell permitía a los Exploradores de España integrar sin grandes contradicciones una propuesta de educación integral, que se fundamentaba en el activismo y en la naturaleza como espacio educativo, con valores propios de la tradición católica, conservadora, monárquica y del patriotismo español. Aunque en principio la creación de los Exploradores de España despertó reservas en la Iglesia Católica, que incluso, como en el caso de Mallorca, creó grupos de scouts católicos, ${ }^{14}$ al final los Exploradores aceptaron la influencia confesional católica. En la difusión de los Exploradores de España fue fundamental el apoyo que recibieron de los poderes tradicionales, la monarquía y la nobleza, los militares y la Iglesia. Desde principios de su creación contaron con el apoyo del monarca y del gobierno. El 26 de febrero de 1920 se le concedió a la organización, por Real Decreto del rey Alfonso XIII, el carácter oficial y nacional. Durante la dictadura militar de Primo de Rivera (1923-1930) el apoyo del poder político a los Exploradores de España se intensificó. Fue durante este periodo cuando la organización tuvo un mayor desarrollo y difusión. ${ }^{15}$

\footnotetext{
${ }^{13}$ María del Mar del Pozo Andrés, Currículum e identidad nacional: regeneracionismos, nacionalismos y escuela pública:(1890-1939) (Madrid: Biblioteca Nueva, 2000).

${ }^{14}$ Mateu Cerdà, L'escoltisme a Mallorca (1907-1995) (Barcelona: Publicacions de l'Abadia de Montserrat, 1999).

${ }^{15}$ Sobre la difusión del escultismo en España, puede verse Fabián Buendía, Los Exploradores de España. Retazos de su historia (Madrid: Imprenta Tutor, 1984). José Ignacio Cruz Orozco, Escultismo, Educación y Tiempo Libre. Historia del asociacionismo scout en Valencia (Valencia: Generalitat Valenciana, Institut de la Joventut, 1995). Anastasio Martínez Navarro, «El escultismo en el marco de la educación física: su implantación en España», en La educación en la España contemporánea.
} 
Esta identificación de los Exploradores de España con el nacionalismo español más conservador y su orientación militarista despertó recelos entre los grupos progresistas del conjunto del Estado. ${ }^{16}$ También fue poco aceptado en Cataluña donde, en esta época, una potente burguesía industrial impulsaba un proyecto de reconstrucción nacional que tenía en la lengua y la cultura catalanas uno de sus ejes vertebradores y en la educación uno de sus principales instrumentos. En 1912 el capitán de caballería Pere Rosselló crea los Exploradores Barceloneses, que sigue las directrices de los Exploradores de España, con una orientación más militarista, centralista y españolista. ${ }^{17}$ Desde el principio ya se creó también una organización scout catalanista, los Jovestels, impulsada por el periodista y político republicano y catalanista Ignasi de L. Ribera Rovira, que utilizaba exclusivamente la lengua catalana y como símbolo la bandera de Cataluña. Esta organización no tuvo ninguna relación con los militares. Los Jovestels tuvieron poca difusión y escasa duración. Hay que esperar hasta 1927 para que se crease una organización scout catalanista de mayor difusión y duración que recibió el nombre de Germanor dels Minyons de Muntanya, conocida como Minyons de Muntanya. La asociación fue creada por el nacionalista independentista catalán Josep Maria Batista i Roca que había conocido el escultismo en Inglaterra. Esta organización, con etapas muy difíciles durante la dictadura de Primo de Rivera, la Guerra Civil y la dictadura franquista, prácticamente pervivió

Cuestiones históricas. Libro homenaje a Angeles Galino, comp. Julio Ruiz Berrio (Madrid: Sociedad Española de Pedagogía, 1985), 151-163. José María López Lacácel, Así fuimos, así somos. Historia de Scouts de España. Exploradores de España (Madrid: Federación de Asociaciones Scouts de España, 2003). Xavier Montilla Salas, «Estatutos y reglamento orgánico de la asociación nacional de los exploradores de España y disposiciones oficiales que afectan a la misma», Historia de la Educación. Revista Interuniversitaria 22-23 (2003-2004): 431-450.

${ }^{16}$ Algunos autores ya criticaron la aplicación del método como una forma encubierta de militarización de la juventud y de preparar para la guerra. Véase Juan Manuel Fernández-Soria, «The presence of the British education model in Spain: reception through the Institución Libre de Enseñanza», History of Education 43, no. 1 (2014): 50-71. En algun trabajo recientes se afirma que los Exploradores de España sirvieron para la exaltación nacional y patriótica muy adecuada para sostener la campaña militar del ejercito español para mantener la colonia de Marruecos inciada el 1909. Xavier Torrebadella Flix, «España, regeneracionismo y deporte durante la I Guerra Mundial», Athenea Digital 16, no. 1 (2016): 237-261.

${ }^{17}$ Sobre el escultismo en Cataluña puede consultarse Eduard Vallory Subirá y Jordi Quera, Excursionisme i escoltisme (Barcelona: Publicacions de 1'Abadía de Montserrat, 1994). Albert Balcells y Genis Samper, L'escoltisme català (1911-1978) (Barcelona: Barcanova, 1993). Genis Samper, 50 anys d'escoltisme cátala. 1927-1978 (Barcelona: Fundació Jaime Bofia, Federació Catalana d'Escoltisme i Guiatge, 1992). Salomó Marqués, L'escoltisme gironí (Girona: Edicions del Pel, 1984). 
hasta 1974, año en que se integró en una organización unitaria de todo el escultismo catalán. Los Minyons de Muntanya se desarrollaron con una relación muy estrecha con los grupos excursionistas catalanes muy activos en aquellos años. Batista i Roca impulsó la creación de los Minyons de Muntanya desde una vocalía del Centre Excursionista de Catalunya, siendo presidente de la sección de folklore y etnografía de aquella institución. En la difusión de los Minyons y en su orientación educativa colaboró el sacerdote Antoni Batlle i Mestre, que en aquellos años había participado en las actividades de diversos centros educativos renovadores y colaborado con la misma María Montessori durante las épocas que esta pedagoga residió en Cataluña. Como ejemplo de las reservas que la utilización del escultismo por la dictadura de Primo de Rivera despertaba entre la burguesía catalana, podemos recurrir a las palabras de Alexandre Galí. Galí, historiador de la cultura y pedagogo representativo de la renovación educativa impulsada por el catalanismo conservador y favorable a las tesis del escultismo, llegaría a afirmar más tarde que «En venir la dictadura militar, els Exploradores van ser un instrument del dictador, que els va atorgar cada vegada una protecció major, cosa que va contribuir a distanciar-los mes del poblé». ${ }^{18}$

Por lo que respecta al escultismo femenino, su creación fue posterior al masculino. Uno de los primeros grupos fue el fundado en 1930 en el Grup Excursionista de Joventut Catalana como sección femenina de la Germanor de Minyons de Muntanya fundado por Josep Maria Batista i Roca el $1927 .{ }^{19}$ Con anterioridad a la Guerra Civil también existió algún grupo de guías scouts en el País Vasco y en otros lugares del Estado. ${ }^{20}$

Con la caída de la Dictadura de Primo de Rivera y durante la II República, los Exploradores de España pierden apoyo oficial y se crean nuevas asociaciones independientes de aquella organización. ${ }^{21}$ En Cataluña las or-

\footnotetext{
${ }^{18}$ Alexandre Galí, Historia de les institutions i del moviment cultural a Catalunya: 1900-1936. Llibre X: Institutions de cultura popular (Barcelona: Fundació Alexandre Galí, 1983), 147.

${ }^{19}$ Albert Balcells y Genís Samper, L'escoltisme català (1911-1978), 11-113.

${ }^{20}$ María Luisa García Rodríguez y Valeria Vittoria Aurora Bosna, «Notas históricas del Guidismo en España (1929-2009)», Historia de la Educación 30 (2011): 195-219.

${ }^{21}$ Jose Ignacio Cruz Orozco, «Entre la Clandestinidad y la Legalidad: El Escultismo Español», en Le Scoutisme. Un Mouvement d'Éducation au XXème Siècle: Dimensions Internationales. Actes du Colloque International tenu à l'Université Paul Valéry, ed. Gérard Cholvy (Montpellier: Editions Montpellier 3, 2002), 249-263.
} 
ganizaciones scouts consiguieron ser independientes de las organizaciones estatales y se creó en el año 1932 la Federació de Boy Scouts de Catalunya.

La dictadura franquista que se impuso después de la Guerra Civil (1936-1939) prohibió las organizaciones scouts e impuso organizaciones juveniles oficiales a imitación de las fascistas italianas y alemanas. Algunos grupos siguieron funcionando en la clandestinidad y fueron el fermento de una muy lenta pero progresiva recuperación en los años cincuenta especialmente por grupos que contaron con el apoyo de la Iglesia Católica.

\section{LOS ORÍGENES DE LOS SCOUTS EN BRASIL Y SU DIFUSIÓN EN EL SUR DEL PAÍS}

El surgimiento del escultismo coincidió con un importante momento político en la historia política de Brasil cuando, a fines del siglo XIX, fue proclamada la República y el país cambió de sistema político. El escultismo y la educación moral y cívica que este comportaba sirvió para imponer disciplina y apoyar la difusión de los ideales republicanos. Por ello en su divulgación participaron los militares y los republicanos. En el año de 1910, fue fundado el Centro de Boy Scouts de Brasil, en Rio de Janeiro. Los impulsores de esta iniciativa fueron oficiales de la Marina, que quedaron impresionados con el nuevo método de educación durante una visita a Inglaterra. ${ }^{22}$ Entre estas personas, se encontraba el teniente de la Marina de Guerra, Eduardo Henrique Weaver. Este militar fue el autor del primer artículo sobre escultismo publicado en Brasil, en 1909, en la revista Ilustração Brazileira, editada en la ciudad de Rio de Janeiro que en aquel momento era la capital federal. El artículo llevaba como título «Scouts e a Arte de Scrutar».

De acuerdo con Thomé, a partir del año de 1914 se crearon grupos de scouts en distintas ciudades brasileñas. El más importante fue la Asociación Brasileña de Scouts, de São Paulo, que ayudó a difundir el movimiento por todo el país. En el año de 1915 ya existían grupos scouts en casi todas las regiones de Brasil. Según Thomé, el presidente de la República,

\footnotetext{
${ }^{22}$ Nilson Thomé, «Escotismo: história de uma prática educativa extra-escolar», en Anais do VI Congresso Luso-Brasileiro de História da Educação (Uberlândia: Universidade Federal de Uberlândia, 2006), 4901-4913.
} 
Wenceslau Braz, sancionó el Decreto del Poder Legislativo n. ${ }^{\circ}$ 3.297, de 11 de junio de 1917, en el que ya en su artículo 1. ${ }^{\circ}$ establecía que las asociaciones brasileñas de scouts eran consideradas de utilidad pública.

Durante y en los años posteriores a la Primera Guerra Mundial, Brasil vivió una fase de fuerte influencia de la ideología nacionalista. Algunos movimientos y campañas de orientación nacionalistas se iniciaron con la finalidad de promover la elevación moral y política del país. ${ }^{23}$ Una de las campañas nacionalistas que más resultado obtuvo fue la del poeta Olavo Bilac. ${ }^{24}$ En el sur de Brasil, en especial en las ciudades de Pelotas y Rio Grande, esta campaña fue la causa de la gran atención que el escultismo recibió de la prensa entre las décadas de 1910 y 1920.

Nascimento es otro autor que pone de manifiesto que el éxito del escultismo, tanto en el ámbito nacional como mundial, estuvo relacionado con un contexto de crisis y de valorización de la idea de nación. ${ }^{25} \mathrm{La}$ defensa que se hacía del método incidía en su capacidad para formar moralmente a los estudiantes y para disciplinar sus cuerpos. La difusión del escultismo, en el que se esforzaron las clases dirigentes tanto a nivel nacional como regional, respondía al objetivo de formar una ciudadanía disciplinada y uniformada en una época en la que cada vez eran más evidentes las diferencias sociales derivadas del Imperio y agravadas en la República. Desde el poder se impulsaba un programa destinado a unificar el modelo de ciudadano «urbanizando» $\mathrm{y}$ "desinfectando» las personas y los lugares destinados a ciertos grupos mediante un proceso de selección/ exclusión de los habitantes. De acuerdo con este objetivo, y como afirma Corsetti, la formación física, intelectual y moral de la juventud —a la que el escultismo podía contribuir de forma importante- se convertía en un instrumento para garantizar el orden y el control social, con el fin de que cada uno aceptase disciplinadamente su función social. ${ }^{26}$

\footnotetext{
${ }^{23}$ Rosa Fátima de Souza, «A militarização da infância: Expressões do nacionalismo na cultura brasileira», Cadernos Cedes xx, no. 52 (2000):104-121.

${ }^{24}$ Olavo Bilac fue un poeta brasileño, republicano y nacionalista. Entre los años 1915 y 1916 emprendió una "cruzada» cívica, visitando varias ciudades de Brasil y divulgando el escultismo, la obligatoriedad del servicio militar, la fundación de la Liga de Defensa Nacional y los ideales del nacionalismo. ${ }^{25}$ Adailson de Oliveira Nascimento, «Educação e civismo: movimento escoteiro em Minas Gerais (1926-1930)», Revista Brasileira de História da Educação 7 (2004): 43-73.

${ }^{26}$ Berenice Cordetti, O poder em migalhas - a escola no Rio Grande do Sul na Primeira República (Santa Maria, Universidade Federal de Santa Maria, 1997)
} 
Como indica Sanson, la propuesta de Baden-Powell no comporta por sí la orientación militarista que su aplicación tuvo en algunos países, como es el caso de España o Brasil. ${ }^{27}$ Así, Nascimento entiende que el proyecto militarizado que se llevó a cabo en Brasil era una cierta manipulación del método de acuerdo con las necesidades de las élites brasileñas de aquella época. ${ }^{28}$ La orientación militarista del escultismo en un clima bélico generalizado, se corresponde y coincide con el resurgimiento de las sociedades de tiro, que tenían como objetivo transformar Brasil en un país preparado para protegerse en cualquier conflicto armado. La militarización de los niños no se percibe como un problema, sino como una forma de defensa.

Aunque el escultismo tuviese mucho éxito en Brasil hasta el año 1924, en que se fundó la União dos Escoteiros do Brasil que consiguió aglutinar los distintos grupos, no existió una organización común que los englobase.

\section{LA FOTOGRAFÍA EN LA DIFUSIÓN DEL ESCULTISMO EN ESPAÑA Y BRASIL}

En 1826 nació la fotografía, pero no será hasta la segunda década del siglo xx y especialmente al final de la I Guerra Mundial cuando ésta llegó a jugar un papel importante en el periodismo. Como ha señalado Jean Pierre-Amar,

la fotografía de información, considerada durante mucho tiempo una simple prueba, se transforma de a poco hasta convertirse en testimonio periodístico, relato, visión de un hombre. Puede traducir la conciencia del testigo privilegiado que está dando su opinión y utiliza sus imágenes como medio de lucha para defender sus ideas y ponerse al servicio de una causa que considera justa. Esta actitud puede tener otra cara y este compromiso transformarse entonces en propaganda. ${ }^{29}$

\footnotetext{
${ }^{27}$ Luiz de Souza R Sanson, «A Educação em tempos de nacionalismo: as representações do escotismo em Laguna-SC (1917-1960)». (Dissertação Mestrado em Educação, Universidade do Estado de Santa Catarina, 2012).

${ }^{28}$ Jorge Carvalho do Nascimento, A escola de Baden-Powell: cultura escoteira, associação voluntária e escotismo de Estado no Brasil (Rio de Janeiro: Imago, 2008).

${ }^{29}$ Jean-Pierre Amar, El Fotoperiodismo (Buenos Aires: Editorial La Marca, 2005). 7
} 
La fotografía encajada en un texto para componer un reportaje tendrá en muchas ocasiones una función publicitaria y propagandística. ${ }^{30}$

Uno de los movimientos que utilizará la fotografía y en general la imagen para publicitarse será la Escuela Nueva cuya difusión coincide con la del fotoperiodismo y la popularización del cine. ${ }^{31} \mathrm{El}$ escultismo, inspirado en los principios de la Escuela Nueva, no escapa a la intervención de las imágenes en su difusión mundial.

En España la publicación Alrededor del mundo, revista ilustrada semanal que se editó en Madrid entre 1899 a 1930, ya publicó el 8 de agosto de 1909 un reportaje sobre el método creado por Baden-Powell. El artículo se titula «Un ejército de chicos escuchas». El texto, acompañado de dos fotografías, describe las características generales del escultismo y destaca su incidencia en la formación práctica, moral y física de los jóvenes. Las fotografías - una patrulla colocando una pasarela en un arroyo y un grupo descansando junto a una tienda de campaña- recalcan gráficamente la uniformidad en la vestimenta, la importancia de la naturaleza en las actividades del escultismo y la atención a la formación de habilidades manuales. ${ }^{32}$ Entre 1912 y 1913 diversos reportajes ilustrados presentando las actividades de los scouts españoles y de otros países fueron apareciendo en distintas revistas como la barcelonesa Ilustración Artística que contenía imágenes de mucha calidad. ${ }^{33}$ La prestigiosa revista madrileña La Ilustración española y americana también se interesó por el tema publicando fotos de los scouts franceses. ${ }^{34}$ En 1913 en el semanario Alrededor del mundo, que había sido pionero en presentar en España las actividades de los scouts, aparece un reportaje de tres planas titulado «Hazañas infantiles los Boy-Scouts Ingleses». El reportaje comienza con-

\footnotetext{
${ }^{30}$ Dolores Sáiz, «Propaganda e imágen: los orígenes del fotoperiodismo», Historia y comunicaciónvisual 4 (1999): 173-182.

${ }^{31}$ La importancia de la fotografía de prensa en la divulgación de otros métodos educativos ya ha sido puesta de manifiesto en trabajos como: Francesca Comas y Bernat Sureda, «Photography and advertising of the Maria Montessori method in Spain (1911-1931)», Paedagogica Historica 48, no. 4 (2012): 571-587.

${ }^{32}$ Alrededor del mundo (Madrid). 18 de agosto de 1909, 100. [http://hemerotecadigital.bne.es/issue. vm?id=0001867852\&page $=6 \&$ search $=$ escuchas\&lang=es $]$.

${ }^{33}$ Ilustración artística. 20 de mayo de 1912, 346. http://hemerotecadigital.bne.es/issue.vm?i$\mathrm{d}=0001617501$ \&page $=14 \&$ search $=$ scouts\&lang $=\mathrm{ca}$

${ }^{34}$ La Ilustración española y americana. 15 de diciembre de 1912, 374. http://hemerotecadigital.bne.es/ issue.vm?id=0001224793\&page $=12 \&$ search $=$ scouts\&lang=ca (consultado el 10-1-2016).
} 
fesando que quiere dar apoyo a la difusión del método en España y darlo a conocer. ${ }^{35}$ Esta crónica continuó en un número posterior de la misma revista ${ }^{36}$ que siguió informando en años posteriores de las actividades de los scouts y especialmente de sus campamentos internacionales (Jamborees).

Por el escultismo no solo se interesaron las revistas generalistas, sino también algunas especializadas. Por ejemplo, en febrero de 1913 la revista España médica, que había sido creada en 1911 por el pediatra y escritor de obras de su especialidad José Ignacio de Eleizegui López. (18791956), incluyó en sus páginas un reportaje sobre los scouts ilustrado con fotografías de los scouts ingleses realizando diversas actividades relacionadas con la sanidad y la higiene. El reportaje recomienda eliminar los aspectos militaristas del sistema al que, por otra parte, considera muy positivo. ${ }^{37}$ Otro ejemplo de reportaje publicado en revistas especializadas es el aparecido en la España forestal en el número correspondiente a agosto, septiembre y octubre de $1919 .{ }^{38}$ En él se da cuenta de un campamento en la sierra de Espuña en Murcia. El reportaje aparece ilustrado con tres fotografías del campamento. En estos primeros reportajes, sin excluirse las actividades sociales de los scouts, dominan las fotografías sobre sus actividades al aire libre y centradas en la formación y desarrollo de habilidades manuales y propias de la vida en el campo.

Con la creación de los Exploradores de España, y especialmente a partir de 1920 en que la organización recibió el apoyo expreso de la monarquía, y durante la dictadura de Primo de Rivera, la prensa gráfica dedicó ya más atención a las actividades de la organización oficial española que al escultismo internacional. Daban cuenta de las actividades de los

\footnotetext{
${ }^{35}$ Alrededor del mundo (Madrid). Doce de marzo de 1913, 202-204. http://hemerotecadigital.bne.es/ issue.vm?id=0001893229\&page $=4 \&$ search $=$ scouts\&lang=es (consultado el 15-3-2016).

${ }^{36}$ Alrededor del mundo (Madrid) 26 de marzo de 1913, 242-244. http://hemerotecadigital.bne.es/issue. vm?id=0001893449\&page $=4 \&$ search $=$ scouts\&lang=es (consultado el 20-1-2016).

${ }^{37}$ España médica (Madrid) 1 de febrero de 1913, 12-14. http://hemerotecadigital.bne.es/issue.vm?i$\mathrm{d}=0005095920 \&$ page $=12 \&$ search $=$ scouts\&lang=es (consultado el 30-6-2016).

${ }^{38}$ España forestal era una revista mensual ilustrada, aparecida en mayo de 1915 como publicación oficial de la Real Sociedad Española de los Amigos del Árbol, impulsada por un ingeniero de Montes de marcado carácter regeneracionista conocido como el «Apóstol del Árbol», por su labor de promoción del amor a la naturaleza en España: Ricardo Codorníu y Stárico (1846-1923). http://hemerotecadigital.bne.es/issue.vm?id=0004978911\&page $=3 \&$ search $=$ exploradores\&lang=es (consultado el 15-4-2016).
} 
scouts españoles, con inclusión de fotografías, revistas como La Unión Ilustrada, La Esfera, Mundo Gráfico, Nuevo Mundo, África o Baleares, por poner ejemplos de revistas generalistas. Los Exploradores de España recibieron también el apoyo, mediante texto y fotografía, de publicaciones deportivas de carácter elitista como la madrileña Gran Vida o la barcelonesa Stadium. Con una mayor atención a los Exploradores de España, la prensa gráfica atiende también más a sus actividades públicas y sociales, participación en ceremonias y desfiles o relaciones con las autoridades, que a sus actividades al aire libre.

La prensa gráfica no dedicó tanta atención a las imágenes de las organizaciones scouts no integradas en Exploradores de España. Solo hemos localizado algunas fotografías de los catalanes Minyons de Muntanya de los que por el contrario se han conservado muchas imágenes en archivos. $^{39}$

En Brasil, así como en España, fotografías del movimiento scout fueron publicadas en la prensa periódica. Entre fines del siglo XIX y comienzos del siglo xx, las revistas ilustradas eran muy usuales en distintas partes del país. Velloso nos informa que fue durante la Primera República que se inició el desarrollo del proceso de comunicación en masa en Brasil..$^{40}$

La revista Fon Fon tenía circulación nacional y era publicada en Rio de Janeiro, que entonces era la capital del país. Lins, ${ }^{41}$ estudioso de la prensa y la historia de la ciudad de Rio de Janeiro, afirma que esa era un centro de discusión política, dominada por ingenieros y por escritores ufanistas, ${ }^{42}$ como Coelho Neto y Olavo Bilac. En los cafés de la ciudad, fueron creados muchos periódicos, diarios y revistas, entre ellos, en el

\footnotetext{
${ }^{39}$ Véase por ejemplo el Arxiu del Centre Excursionista de Catalunya que se puede consultar en formato digital en Memòria Digital de Catalunya. http://mdc1.cbuc.cat/index.php (consultado el 30-6-2016). ${ }^{40}$ Mônica Pimenta Velloso, "As distintas retóricas do moderno», en Cláudia de Oliveira, $O$ moderno em revistas: representações do Rio de Janeiro de 1890 a 1930 (Rio de Janeiro: Garamond, 2010), 43-110.

${ }^{41}$ Vera Lins, "Em revistas, o simbolismo e a virada do século», en $O$ moderno em revistas: representações do Rio de Janeiro de 1890 a 1930, ed. Cláudia de Oliveira (Rio de Janeiro: Garamond, 2010), 15-42.

${ }^{42}$ Eran considerados ufanistas las personas nacionalistas. Sobre este tema, consultar Berenice Corsetti, «Controle e ufanismo: a escola pública no Rio Grande do Sul (1889-1930)», Revista História da Educação 2, no. 4 (1998): 57-75
} 
año de 1907, la revista Fon Fon. Este periódico relacionaba, con ironía, literatura y fotografías de modernización de la ciudad. Sin embargo, es importante mencionar que, en la década de 1920, la revista tenía una dirección más tradicional y relacionada con los intereses políticos republicanos.

No fue hasta 1922, centenario de la independencia de Brasil, que Fon Fon publicó diversas imágenes de los scouts. Esta revista se caracterizó por no relacionar necesariamente las fotografías con noticias específicas. En el número 4 hay dos fotografías del Festival de Escultismo de los scouts de Gavea. Junto a las imágenes, había el siguiente texto:

Festival de Escotismo: os Escoteiros da Gavea. Aquelles escoteiros pertencentes ao 8. ${ }^{\circ}$ Grupo da Associação de Escoteiros Cathólicos do Brasil, em exercícios, no campo do Carioca Foot-Baal Club, por occasião da festa alli por eles promovida, domingo último. ${ }^{43}$

En el número 29, hay una imagen de la fiesta de los scouts católicos, titulada: «En el campo del Hellenico Foot-ball Club. La fiesta de los Scouts Católicos». Abajo aparece la información: "Grupo general, en ocasión de la tarde deportiva como homenaje a los heroicos aviadores portugueses Gago Coutinho y Saccadura Cabral». ${ }^{44}$ En el número 38, en la sección "Grandes Conmemoraciones, la parada de la infancia», fue publicada la fotografía de los Scouts de las Escuelas Agrícolas (Patronatos Agrícolas), con el subtítulo: "Os Escoteiros dos Patronatos Agrícolas, inmobilizados en irreprehensível formatura, na praia do Russel». La imagen reproduce algunas filas de boy scouts, retratadas en un ángulo oblicuo para que la perspectiva de la impresión de la presencia de un gran número de jóvenes.

La misma revista publicó, en el número 40, siete fotografías de la inauguración de la carretera entre São Paulo y São Roque. Una de las imágenes se refiere a los scouts de São Roque, que desfilaban en homenaje al presidente del Estado de São Paulo.

\footnotetext{
${ }^{43}$ Antes de la existencia de una Asociación Scout, los grupos se originaban en contextos distintos: algunas asociaciones católicas crearon grupos scouts, así como los Ayuntamientos y las escuelas públicas crearon escuelas de escultismo laicas.

${ }^{44}$ En 1922, los dos aviadores realizaron la primera travesía aérea del Atlántico Sur en un hidroavión.
} 
Por fin, el número 48 contó con una fotografía publicada bajo el título «A instrucção no estado do Rio. Inaugurou-se o Grupo Escolar D. Pedro II, em Petrópolis». La leyenda de la imágen informaba «Os alumnos, em formatura, vestidos de escoteiros, e que executaram diversos exercícios». Además de la fotografía de los estudiantes, hay otras nueve imágenes, muchas del predio de la escuela, otras de docentes y autoridades y dos de las estudiantes, realizando ejercicios. La noticia contó con texto periodístico que trataba de la educación patriótica y de la fundación de la escuela, en el año del centenario de la independencia.

El periódico Diario Popular era publicado en la ciudad de Pelotas, en el sur de Brasil y tenía una difusión regional. El diario fue fundado el 27 de agosto de 1890 y era el órgano de la prensa del Partido Republicano Rio-Grandense durante toda la Primera República. En este periódico fueron publicadas, entre 1916 y 1930, cuatro imágenes de boy scouts. En 1916, el periódico publicó la fotografía de un niño vestido de boy scout, junto a la noticia sobre la visita del poeta Olavo Bilac, organizada por el Tiro 31. La noticia ocupaba casi toda una página y presentaba informaciones completas sobre el evento. En el mismo año, junto a un texto nacionalista sobre el poeta Olavo Bilac, su cruzada por el civismo y su visita al estado de Rio Grande do Sul, fue publicada una fotografía de una acampada de scouts, con el siguiente subtítulo: «Un acantonamiento de scout boys, institución que, por iniciativa del patriótico Tiro 31, será inaugurada hoy por el poeta Olavo Bilac». La fotografía no informa que grupo de escultismo era el retratado.

En 1917 fue publicada una fotografía de dos niños, vestidos de boy scouts, bajo el título «Escoteiros de Pelotas». La fotografía acompañaba la noticia de que los dos jóvenes que pertenecían al Grupo de Escultismo acompañaron el Tiro $31^{45}$ (de Guerra), en su entrenamiento, en marcha

\footnotetext{
45 Como se ha indicado anteriormente, en Brasil la fundación de algunos de los grupos de boy scouts fue impulsada por las Sociedades de Tiros, más conocidas como Tiros de Guerra, que eran clubes para practicar el tiro frecuentados por hombres que ocupaban altas posiciones políticas y sociales. El número de estas sociedades creció mucho durante fines del siglo xix y comienzos del siglo xx. Con la llegada del escultismo al Brasil, estas sociedades percibieron la posibilidad de desarrollar espacios para que los niños realizasen una formación cívica y física. Cuando la participación de estas sociedades en la fundación de grupos de escultismo fue importante, las actividades realizadas fueron fuertemente militarizadas y orientadas a los valores patrióticos.
} 
por $36 \mathrm{~km}$. La fotografía no retrataba a los jóvenes de uniforme, sino vestidos con ropa normal y corbata. En 1925, el diario publicó la fotografía de tres scouts, junto a la noticia titulada «Sed scouts de Brasil», sobre el discurso proferido por Fernando Osório en la fundación del Grupo de Scouts del Colegio Cassiano do Nascimento.

Otro periódico regional fue el Almanach de Pelotas, publicado entre 1913 y 1934. Sus primeras ediciones fueron realizadas por Ferreira \& Cia. Pero en 1917 Florentino Paradeda asumió la edición del periódico y este pasó a realizar propaganda y registrar el progreso de la ciudad y región. El periódico publicó tres imágenes de los scouts. En 1918, una fotografía de los scouts realizando un ejercicio con bordones en la Plaza de la República participando en conmemoraciones cívicas. En 1926, una fotografía del Grupo de Scouts del Patronato Agrícola saludando a la bandera nacional, realizada en la institución de enseñanza. Los jóvenes formaban dos filas. En 1929 fue publicada la fotografía del Grupo Municipal de Scouts en la escalera del Grupo Escolar Dr. Joaquim Assumpção, donde se encontraba un gran grupo de niños que vestían el uniforme de scouts.

\section{LA ICONOGRAFÍA SOBRE LAS PRIMERAS DÉCADAS DEL ESCULTISMO}

La comprensión de la función social de la fotografía en las primeras décadas del siglo xx requiere la investigación histórica del papel de la imagen fotográfica a partir del siglo XIX, en el momento de su creación. Fabris afirma que pensar la fotografía en sus múltiples relaciones con la sociedad del siglo XIX, implica analizarla con base en sus especificidades de imágenes de consumo, de imágenes impresas y multiplicadas. ${ }^{46}$ Las fotografías publicadas en la prensa ilustrada constituyen imágenes de consumo y tienen una gran importancia en una sociedad que llegó a comienzos del siglo XIx iletrada. Además, las características atribuidas a las fotografías de confiabilidad y veracidad, fueron fundamentales para la finalidad que se les quiso dar en el discurso de los reportages en los que se incluyan.

\footnotetext{
${ }^{46}$ Annateresa Fabris (org.), Fotografia usos e funções no século XIX (São Paulo, Editora da Universidade de São Paulo, 1991).
} 
Las fotografías publicadas en Brasil, en general, retratan a los boy scouts en conmemoraciones y festividades. Uno de los motivos relacionados con esta práctica se refiere a los gastos con la producción de las fotografías. De esa manera, los temas más ceremoniales son aquellos a los que se dedican la mayor parte de las imágenes, tanto a nivel nacional, como regional. Aunque Brasil no haya tenido, durante la Primera República, una única asociación nacional de boy scouts, sino grupos de distintas localidades, ligados a escuelas regulares o a sociedades de Tiro, las imágenes son muy semejantes. Las diferencias entre las fotografías publicadas en periódicos de circulación nacional y regional estriban en que los periódicos regionales, a diferencia de los nacionales, sí identifican quienes son los scouts.

En las noticias sobre los grupos de scouts, se menciona las actividades al aire libre pero, en contraste, se encuentran pocos registros gráficos sobre ellas, como la fotografía de la acampada, publicada cuando se creó el Grupo de Scouts de la ciudad de Pelotas. Esa fotografía se distingue de las demás, porque presenta un grupo de jóvenes en una actividad de campo.

Una de las instituciones educacionales que se relaciona directamente con los grupos de escultismo son las escuelas agrícolas, que tuvieron como con objetivo configurar un espacio de formación para los jóvenes «desvalidos de la fortuna», para los niños de familias pobres que eran, según se entendía en aquella época, un colectivo necesitado de higiene moral. Así, las actividades extraescolares de los scouts, sus manifestaciones de civismo y buen comportamiento, eran consideradas ideales para que los niños no acabasen en la delincuencia y la criminalidad.

No hay fotografías de girl scouts en Brasil, en ese período. Hay registros de tentativas de implementación de grupos de girl scouts (denominadas bandeirantes), pero no se desarrollaron durante la Primera República. Así que todas las imágenes retratan a niños del sexo masculino. Además, aunque la calidad de las fotografías no permita afirmarlo con rotundidad, la mayoría de ellos son jóvenes blancos. Se percibe la presencia de niños negros, pero son más bien una excepción entre una mayoría de blancos. 
En España la clave para entender el discurso iconográfico que sobre el escultismo construye la prensa gráfica es igualmente la mayor o menor atención a las actividades desarrolladas en el aire libre o a las que representan ceremoniales y participación en actividades protocolarias. La presentación de imágenes de las actividades de los scouts en el campo, están más relacionadas con los principios de educación integral que son propios del método desarrollado por Baden-Powell. Las que presentan la participación de los scouts en espacios cerrados, o en formaciones paramilitares, ponen de manifiesto su función en la formación de valores patrióticos tradicionales y de obediencia al poder establecido. El primer tipo de imágenes nos presenta a los scouts desarrollando sus capacidades mediante la actividad en el medio natural, colaborando con sus compañeros y esforzándose por mejorar y ayudar a los otros. En España la utilización por la monarquía y la dictadura de Primo de Rivera de la organización scout se traduce, en las fotografías publicadas, en imágenes que muestran la docilidad de la organización de los Exploradores de España con las autoridades mediante formaciones militares, banderas y otros símbolos que nos muestran una organización orientada a disciplinar a los jóvenes al servicio del nacionalismo español, que en esta época se pretendía desarrollar desde el poder.

En la imagen 1 podemos ver un grupo de exploradores que, como dice el pie de foto, están preparados para la marcha. Representa una formación, ordenada y disciplinada y forma parte de un reportaje de cinco páginas presentando los Exploradores de España, que incluye cinco fotografías sobre las actividades de este grupo. La combinación entre texto e imágenes nos da muchas pistas para comprender el mensaje icónico que se quiere transmitir. Se señala que los objetivos de los Exploradores son:

Educar a la juventud española a la paz física y moralmente; desarrollar en ella no sólo los músculos sino también los sentimientos nobles y generosos, el amor a la Patria y a sus conciudadanos; crear hombres fuertes, útiles y honrados; hacerles profesar el culto del honor y del desinterés; inculcarles el respeto a las leyes y además combatir el defecto nacional del miedo al ridículo, causa muchas veces de que los españoles no realicen determinados actos en beneficio de sus semejantes. 


\section{LOS EXIPLORAIDORES DE ESPANNT}

\section{(Boy scouts españoles.)}

Educar á la juventud española á la paz fisica y moralmente; desarrollar en ella no sólo los músculos sino también los sentimientos nobles y generosos, el amor á la Patria y á sus conciudadanos; crear hombres fuertes, útiles y honrados; laccrles profesar el culto del honor $y$ del desinterés; inculcarles el respeto á las leyes y además combatir el defecto nacional del micdo al ridiculo, causa muchas veecs de que los espatioles no realieen determinados actos en beneficio de sus semejantes, es latbor que merece el aplauso de todos los buenos espanoles y $\mathrm{cl}$ apoyo, en la medida de sus fuerzas, de todos los hombres hourados,

1:I bravo defensor de Mafeking, el General inglés sir Robert Baden-Powell, inspirindose en las enscñanzas de la guerra del Trans-

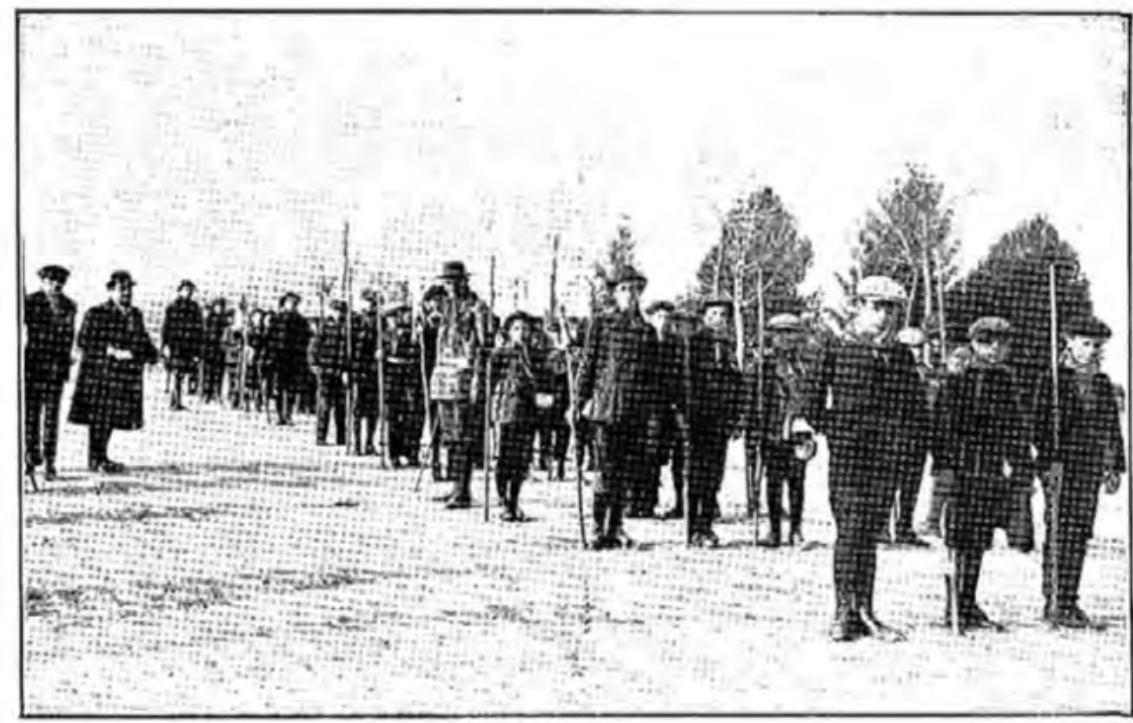

Lox explozadorss propurdetes para la marela,

Imagen 1. Gran Vida (Madrid), 115 (1 de diciembre de 1912), 367.

Hemeroteca Digital. Biblioteca Nacional de España

Vemos como mediante la combinación de texto e imágenes se va construyendo un discurso de moralización patriótica al servicio de la consecución de una juventud disciplinada imbuida de los valores cívicos más útiles para las clases dirigentes. En el artículo se resalta 
que los creadores de la organización ya han afirmado claramente su voluntad de adaptar los principios generales de los scouts a las características y costumbres de los españoles poniéndoles un nombre en lengua española y no utilizando términos extranjeros. El discurso patriótico se refuerza icónicamente con una de las fotografías de la formación cuyo pie indica que están dando vivas a España. Más allá de las muestras de disciplina representadas por las formaciones, no existen en el texto, ni en las imágenes, referencias o simbologías militares. Sí que se señala en el texto el apoyo que la organización ha recibido del monarca, de la nobleza y del ejército. El reportaje apareció en la revista Gran Vida en 1912. Era una revista dirigida a un público que se interesaba y participaba en deportes que en aquella época eran elitistas como la hípica, el polo o el automovilismo. De hecho, apareció en 1903 como órgano oficial de la Sociedad Hípica Española y de Madrid Polo-Club, por lo que sus suscriptores debían de pertenecer a las clases altas de la sociedad. Su subtítulo fue: Revista ilustrada de sports y sociedad. Desde 1908 añade los lemas: turismo, deportes, fotografía y páginas financieras.

Otro conjunto de fotografías que nos pueden ayudar a comprender cómo contribuyen estas a construir el discurso oficial sobre los Exploradores de España, son las que se publicaron en la misma revista Gran Vida en el número 131 de abril de 1914. El reportaje se refiere a la primera asamblea de los exploradores en Madrid que había tenido lugar aquel mes. En las imágenes se combinan dos mensajes. El primero se fundamenta en un discurso higienista que recalca la importancia del ejercicio y de las actividades campestres y al aire libre como una forma de alejar a los jóvenes de otros lugares poco sanos, mencionándose específicamente los cines como ejemplo de estos espacios. El segundo es el del apoyo que dan a la asociación, la monarquía, la nobleza y el ejército. La imagen 2, que forma parte del reportaje mencionado, está formada por un conjunto de tres fotografías que aparecen en bloque en la publicación representando las actividades campestres y deportivas de los Exploradores. En la fotografía central, la reina atraviesa un puente construido por los Exploradores. En otras fotografías del reportaje, aparece el rey Alfonso XIII también presente en el acto. 

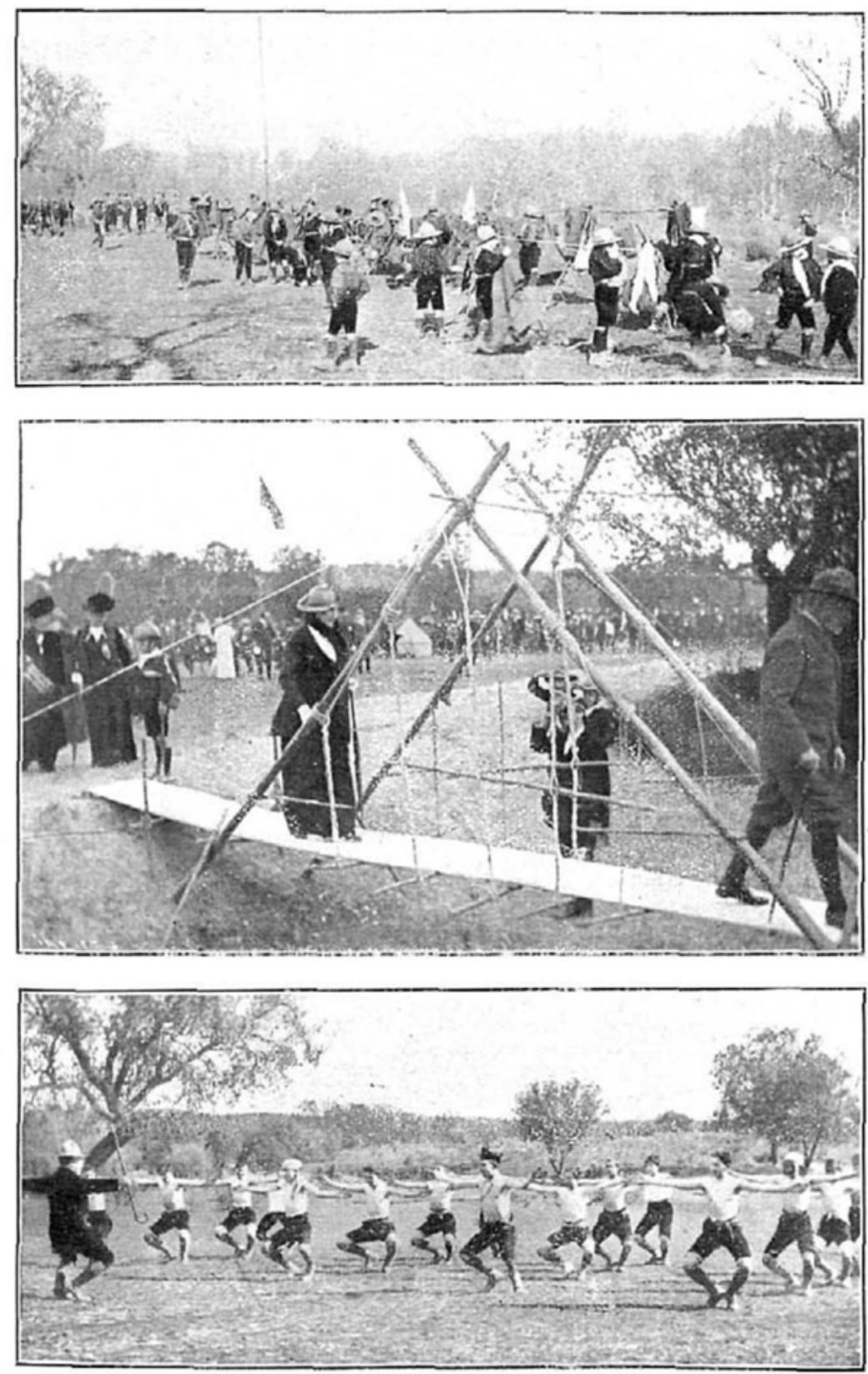

1. Los exploradores instalando el campamento. -2 . La Reina atravesando una pasarela. 3. Los subinstructores haciendo gimnasia sueca.

Imagen 2. Gran Vida (Madrid), 131 (1 de abril de 1914), 101.

Hemeroteca Digital. Biblioteca Nacional de España. 
La relación de los Exploradores de España con las clases dirigentes se observa también en las imágenes que publica la prensa de Barcelona sobre la rama catalana de esta organización constituida por los Exploradores Barceloneses. Las actividades de los Exploradores de España se convierten en actos patrióticos presididos por las autoridades monárquicas representantes del Estado central en una Cataluña donde el catalanismo conservador y el republicanismo habían desplazado de las instituciones locales — diputaciones y ayuntamientos- a los partidos monárquicos. En la imagen 3 podemos ver la presidencia, con el Gobernador Civil al frente, y la magna formación de Exploradores uniformados con ocasión de lo que llaman, utilizando una terminología militar, «la Jura» de los Exploradores Barceloneses. La reproducción de imágenes de las actividades en las que los scouts abandonan la naturaleza, como espacio habitual de sus actividades, para participar en actos sociales, difumina su carácter de método de enseñanza activo para recalcar la vertiente de organización destinada a disciplinar la juventud y ponerla al servicio del poder.

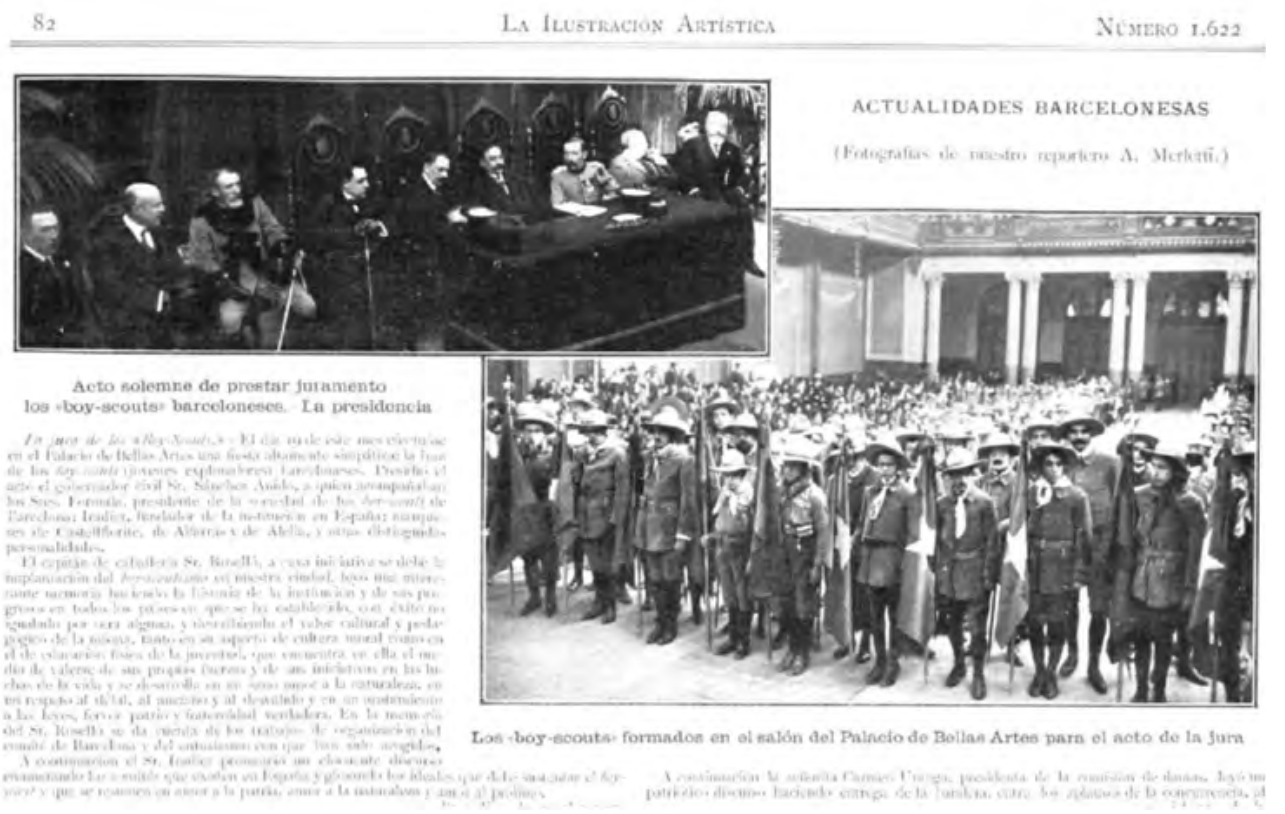

Imagen 3. La Ilustración Artística (Barcelona), 1622 (27 de enero de 1913), 82. Hemeroteca Digital. Biblioteca Nacional de España 
El mismo mensaje de obediencia de los Exploradores Barceloneses a las autoridades monárquicas españolas, y de prioridad de la inculcación de los valores patrióticos y militaristas, la podemos ver en la imagen 4 incluida en la noticia publicada por Mundo Gráfico en 1928 en plena Dictadura de Primo de Rivera. En este caso el que preside, para reforzar el carácter militar del acto, ya no es una autoridad civil sino militar. La Dictadura de Primo de Rivera desarrolló en Cataluña una política contraria a cualquier manifestación de identidad catalanista. El capitán general de Cataluña que preside el acto que se reproduce en la fotografía, Emilio Barrera, fue el ejecutor de un conjunto de medidas que pretendían imponer un nuevo orden que frenase las acciones de descontento social y la creciente orientación nacionalista catalana en el mundo institucional y cultural de Cataluña. Un discurso que además contenía elementos populistas fundamentados en la necesidad de moralizar la vida pública envilecida por la corrupción y el caciquismo. Como ya indicaba A. Quiroga hace unos años: "La formación de ciudadanos "modernos", convenientemente adoctrinados en postulados nacionalistas españoles de corte antidemocrático, se convirtió en el objetivo prioritario del sistema educativo primorriverista». ${ }^{47}$ Los Exploradores de España y su organización en Cataluña podían ser utilizados perfectamente con esta finalidad.

La presencia de los boy scouts en el espacio público fue constantemente retratada en la prensa. Un buen ejemplo de ello es la fotografía del desfile de los boy scouts, en homenaje al presidente de la Provincia de São Paulo, con motivo de la inauguración de la carretera entre São Paulo y São Roque (imagen 5). Como se ha mencionado anteriormente, fueron publicadas siete fotografías acerca de la inauguración y los scouts figuraban en una de ellas.

\footnotetext{
${ }^{47}$ Alejandro Quiroga Fernández de Soto, «Educación para la ciudadanía autoritaria. La nacionalización de los jóvenes en la dictadura de Primo de Rivera», Historia de la Educación 27 (2008): 88
} 
El acto de la promesa de los Exploradores de Barcelona

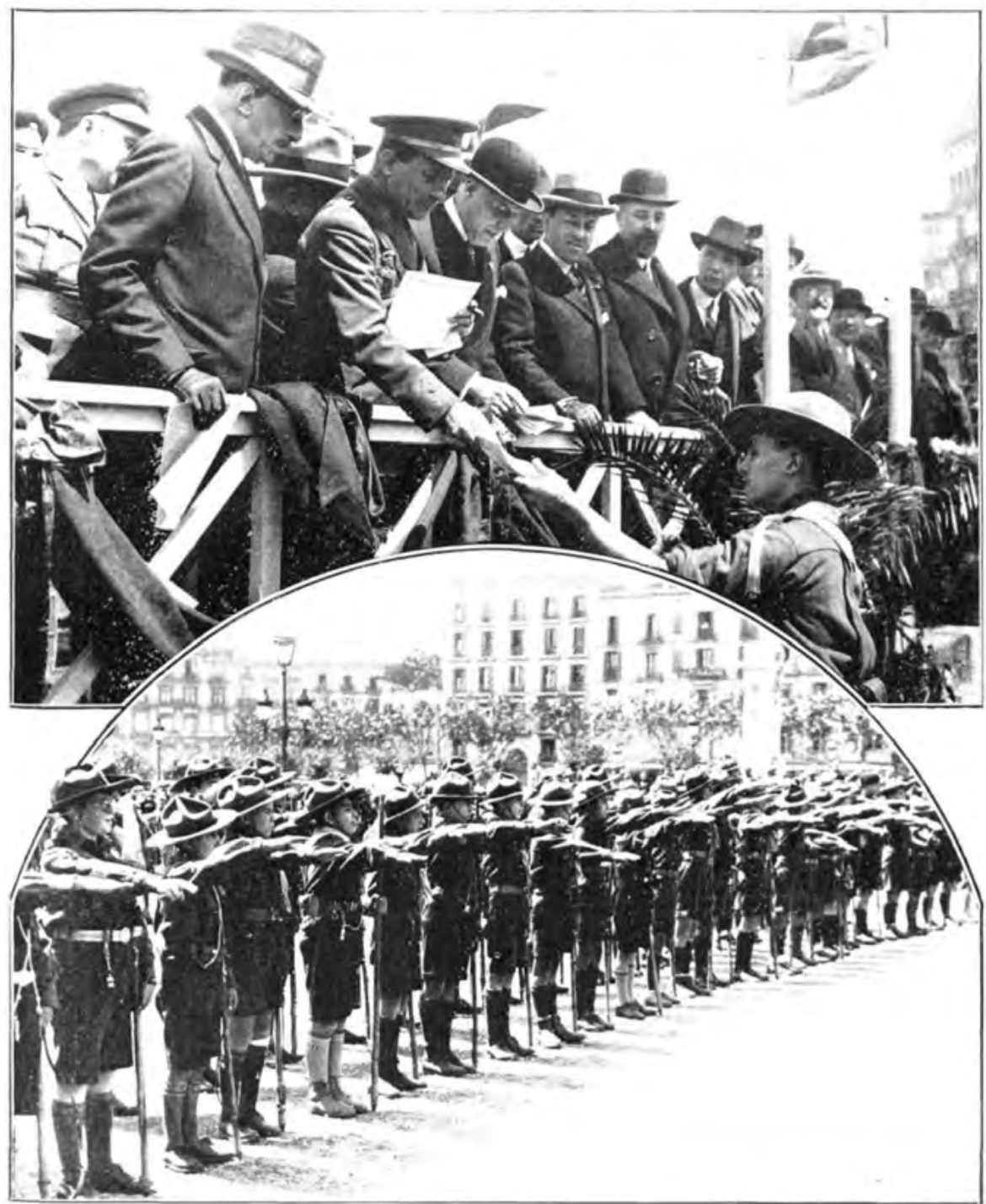

El capitan general 5r. Burrera, con las autoridades, entregando los diplomas a los nuevos Exploradores. Los nuevos Exploradores en el momeato de hacer la promesa, acto electuado el domingo último en la plaza de Cataluña

Imagen 4. Mundo Gráfico (Madrid), 862 (9 de mayo de 1928), s.p.

Hemeroteca Digital. Biblioteca Nacional de España 


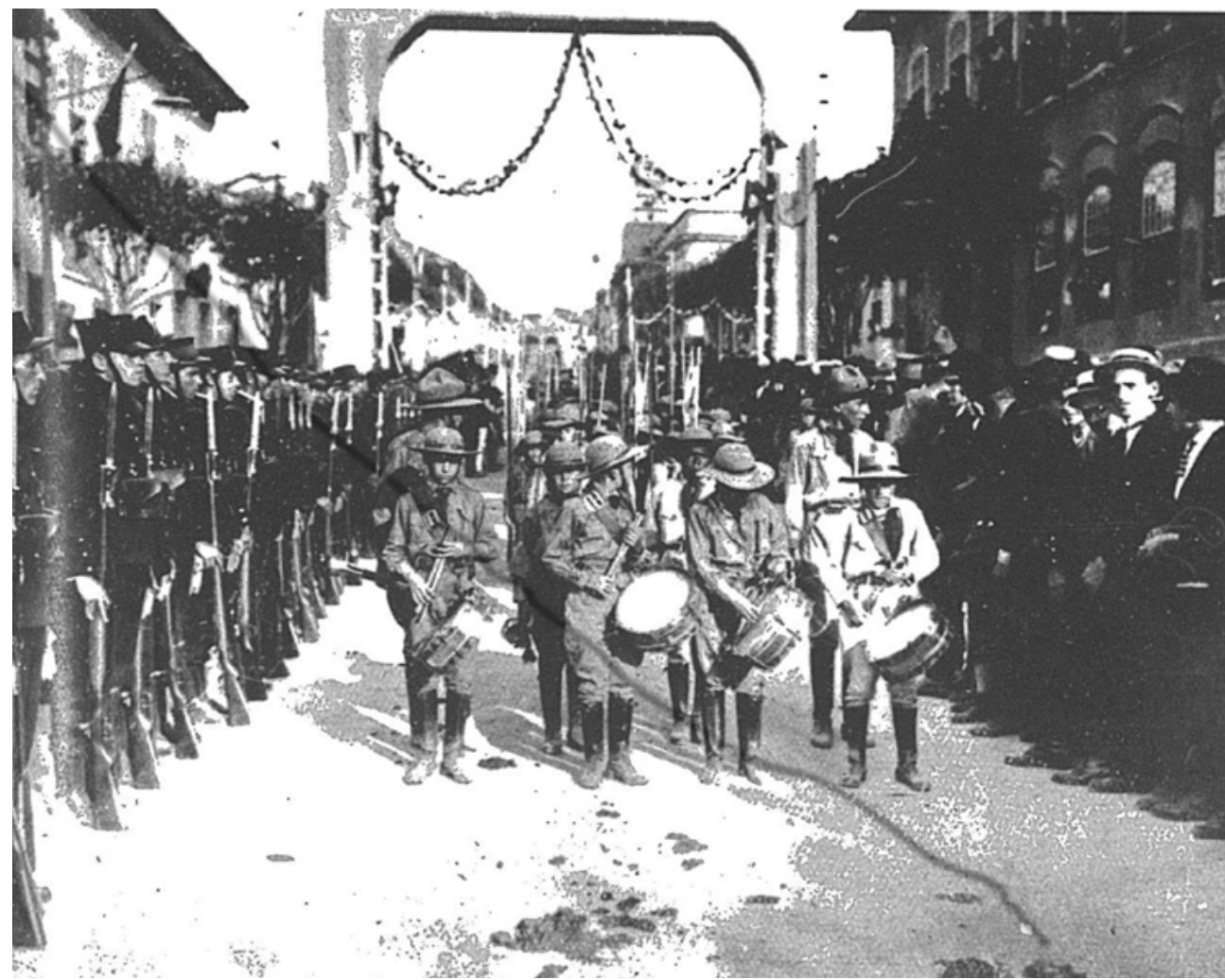

Imagen 5. Fon Fon (Rio de Janeiro), 1922, no. 40. Archivo Digital.

Biblioteca Nacional de Brasil.

La construcción de la carretera entre São Paulo y São Roque ocurrió en un período de modernizaciones urbanas y de utilización política de las obras públicas. Es importante decir que el presidente de la provincia de São Paulo, en el momento de la inauguración de la carretera, era Washington Luis, que fue, pocos años después, presidente de Brasil. La relevancia de la solemnidad representa el intento de mostrar la importancia social de la obra construida y la participación de los scouts demuestra el importante papel que se les concedía en aquella sociedad. El grupo de boys scout se encuentra en el centro de la fotografía, los de delante llevan instrumentos musicales, los de atrás bordones en las manos. El desfile es seguido, en uno de los lados, por población civil; en el otro. vemos una formación militar con uniformes de gala y las armas en posición de descanso, escenografía que refuerza la importancia del evento. 


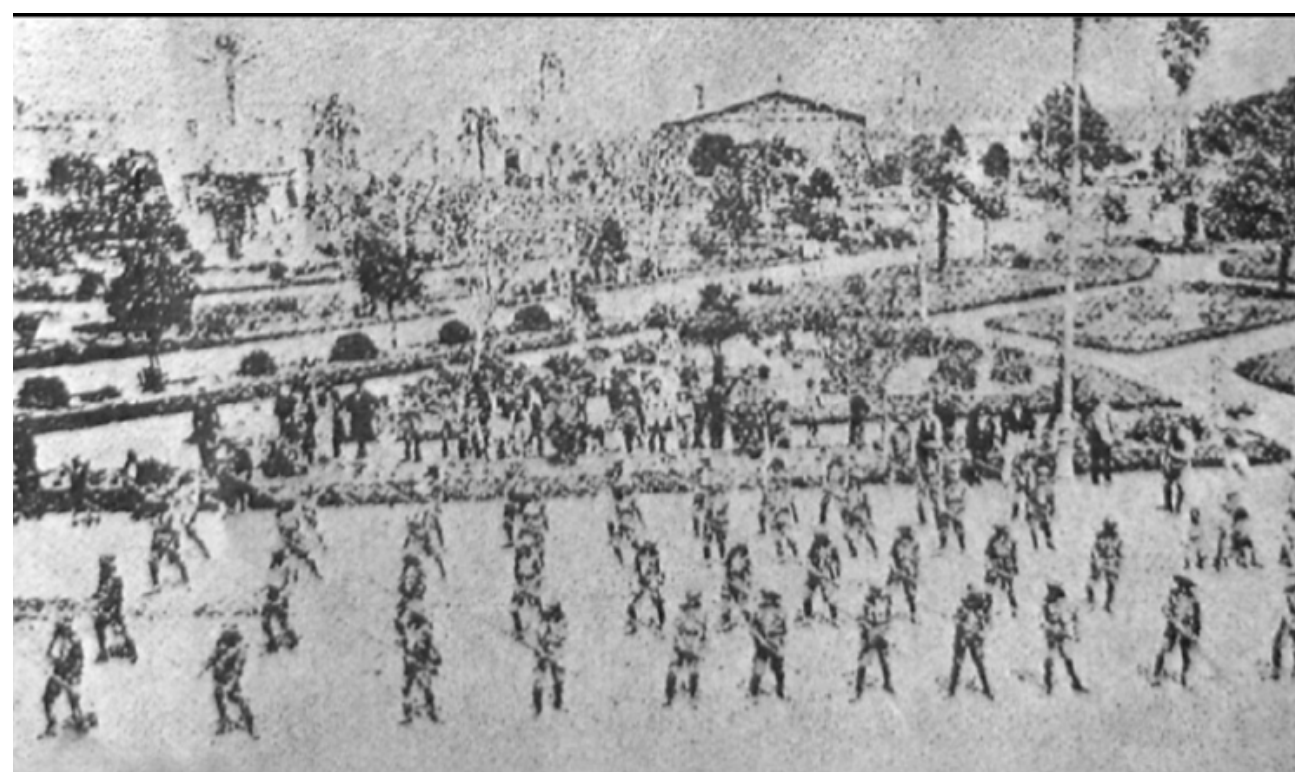

Imagen 6. «Exercício de Esgrima de Vara-pau, á Praça da República», Almanach de Pelotas (Pelotas), 1918. Archivo de Obras Raras. Bibliotheca Pública Pelotense

En la imagen 6, un grupo de boy scouts participa en una celebración contemplada por el público. El grupo aparece impecablemente vestido con el uniforme típico de los scouts: botas, pantalones cortos, camisa y sombrero. Cada uno de los jóvenes esgrime el bordón realizando movimientos con él. Los jóvenes conforman una formación que tiene forma de trapecio, y se combina con la distribución geométrica de los parterres y la vegetación de la plaza de la República. El conjunto trasmite una clara imagen de disciplina casi militar. La similitud de los ejercicios que están desarrollando con un adiestramiento militar es evidente. Representan el orden y la obediencia que se quiere inculcar a los jóvenes. La presencia de estos scouts en una plaza central de la ciudad recalca, como en otras fotos, la relevancia social que quiere darse a su organización.

Las fotografías publicadas por las revistas muestran un escultismo puesto al servicio del nacionalismo y el patriotismo. Recurriendo nuevamente a las imágenes 5 e 6 , es posible retomar la cuestión de la militarización de los jóvenes, que se percibe no sólo por el uniforme, sino también por su postura. La disciplina de los cuerpos forma parte 
también de los objetivos de la instrucción militarizadora. La militarización del discurso oficial de esta época en Brasil se alimentó con el clima creado por la Primera Guerra Mundial. Como ya se ha indicado, la creación de los grupos scouts en muchas ciudades brasileñas fue consecuencia de la campaña cívica de Olavo Bilac, que proponía, como se ha indicado, el servicio militar obligatorio, y con su poesía y oratoria apelaba a los sentimientos patrióticos mientras el mundo vivía su primera gran guerra. La confrontación bélica despertó en Brasil la preocupación por la seguridad nacional. La forma de entender el escultismo en el Brasil de aquellos años respondía a esta inquietud beligerante y atenta a preparar mecanismos de defensa. Como se afirmaba en la prensa:

O movimento geral que se manifesta no paiz a favor da defesa nacional, reorganizando-se sociedades de tiro, augmentado, de uma maneira digna de encomicos, os voluntários de manobras, faz nascer a esperança de, em futuro próximo, ser o Brasil uma nação regularmente forte, formada d'homens capazes de defender o solo pátrio com ardor e intelligentemente ${ }^{48}$

En el contexto de la confrontación bélica, el escultismo se difunde muy ligado al resurgimiento de las sociedades de tiro, que tenían como objetivo transformar a Brasil en un país preparado para protegerse en cualquier conflicto armado. La militarización de los niños y el país no se percibe como un problema o aspecto negativo, sino como una forma de garantizar la defensa y la libertad de la patria y de sus ciudadanos:

Esse movimento não trará em resultado a militarisação do paiz com o fim de aggredir, mas sim a generalização dos conhecimentos de guerra indispensáveis a um povo que quer subsistir, mantendo intacta a sua honra e integral o seu territorio. ${ }^{49}$

De acuerdo con esta lógica, el escultismo era visto como un medio de preparar a los niños para incorporarse a una ciudadanía comprometida con la defensa del pais: «Mas é preciso ir mais longe, é necessário prepa-

\footnotetext{
${ }^{48}$ Opinião Pública, 31 de agosto de 1916.

${ }^{49}$ Opinião Pública, 31 de agosto de 1916.
} 
rar a creança para que com mais facilidade possa, mais tarde, usufruir as grandes vantagens das linhas de tiro ${ }^{50}$ Esto no se produjo solamente en el sur del país, como es posible percibir abajo:

A militarização da infância ressurgia de forma mais sistematizada e racionalizada sob os auspícios dos órgãos da administração do ensino público e a Associação Brasileira de Escotismo. As práticas cívico-militares em voga nas escolas primárias atendiam, assim, a múltiplos propósitos: fosse a perpetuação da memória histórica nacional, a exibição das virtudes morais e cívicas inscritas na obra formativa escolar, a ação educadora da escola para o conjunto da sociedade ou a expressão do imaginário sociopolítico da República. ${ }^{51}$

Souza, en su investigación sobre la militarización de la infancia en las primeras décadas del siglo xx, afirma que las autoridades encargadas de la administración de la enseñanza en São Paulo empezaron el proceso de implementación del escultismo en las escuelas públicas. Cabe indicar que la legislación educativa que se dictaba en esta provincia que era la región más desarrollada económicamente, marcaba la pauta a toda la educación nacional. En ese sentido, muchas escuelas públicas realizaron la implementación del escultismo y no solamente las escuelas primarias, sino también las profesionales. Hay muchos trabajos sobre las escuelas agrícolas creadas a comienzos del siglo xx y la mayoría de ellas contaba con grupos de boy scouts. Las clases de escultismo eran obligatorias. Esas instituciones eran escuelas de educación profesional y atendían a los jóvenes de las clases sociales más pobres. Eran centros tenían una función preventiva y correctiva de la delincuencia juvenil. De esa manera, la formación profesional era considerada como un recurso para evitar la criminalidad. En estos centros el escultismo era un elemento complementario para inculcar la disciplina y la formación patriótica, cívica y moral. Como se ha mencionado anteriormente, dos fotografías de grupos de boy scouts de estas instituciones fueran publicadas, una en la revista Fon Fon y otra en el Almanach de Pelotas.

\footnotetext{
${ }^{50}$ Opinião Pública, 31 de agosto de 1916.

${ }^{51}$ Souza, «A militarização da infância», 116.
} 


\section{AS GRANDES COMMEMORAÇÕES}

A brilhante parada

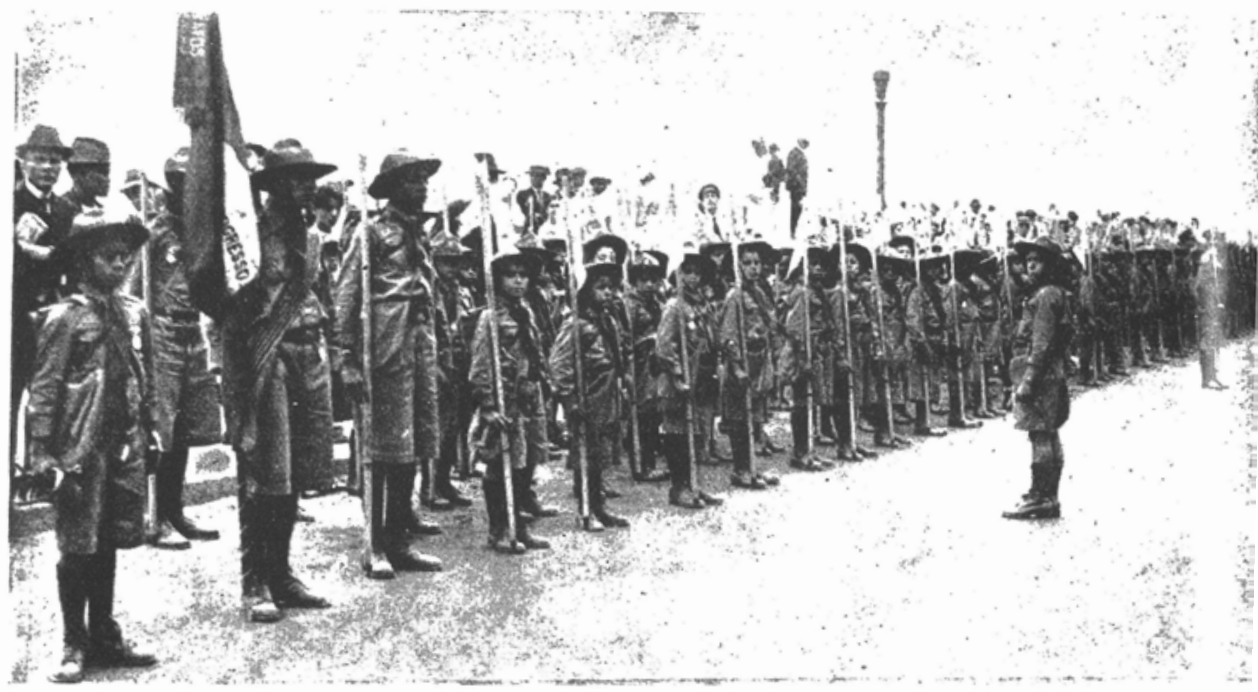

Os escoteiros dos Patronatos Agricolas, immobilizados en irreprehensivel formatera, na praia do Russel.

Imagen 7. «Os Escoteiros dos Patronatos Agrícolas, inmobilizados en irreprehensível formatura, na praia do Russel», Fon Fon (Rio de Janeiro) 38 (1922), 86. Archivo Digital.

Biblioteca Nacional de Brasil.

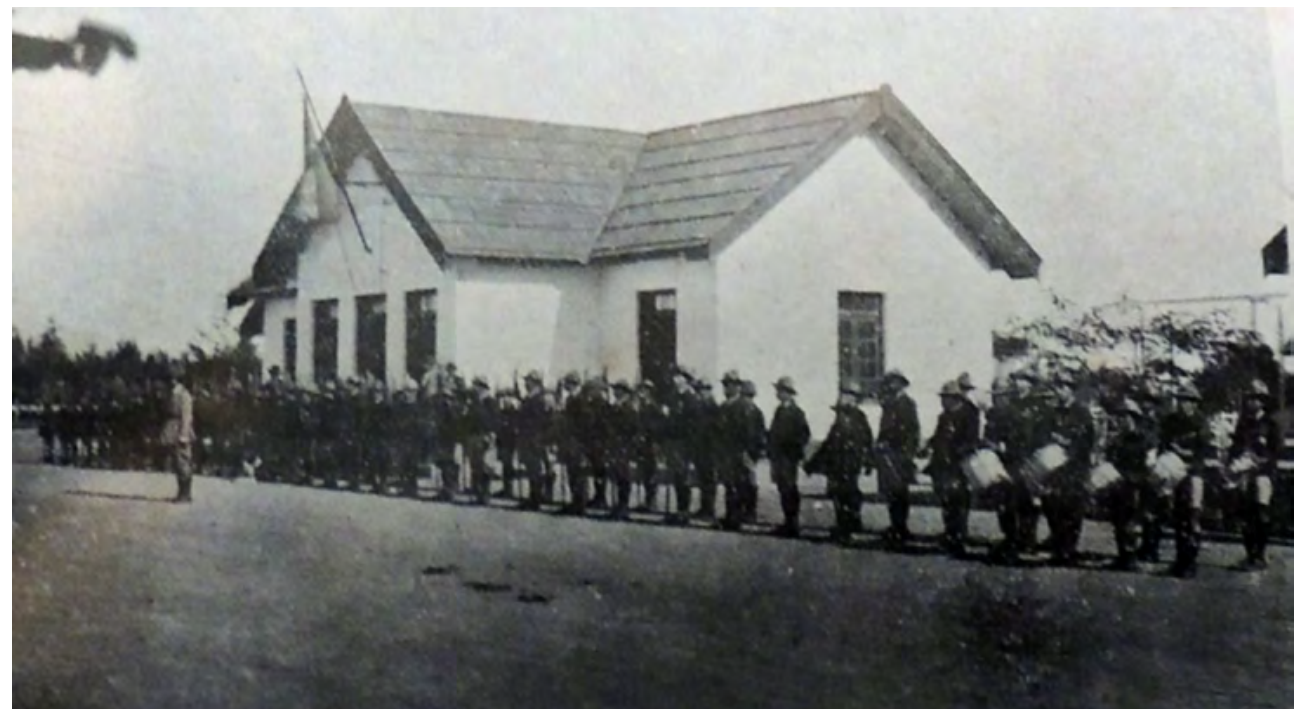

Imagen 8. «Em continencia á Bandeira - Escola de Escoteiros do Patronato Agrícola «Visconde da Graça», Almanach de Pelotas (Pelotas), 1926. Archivo de Obras Raras. Bibliotheca Pública

Pelotense 
La imagen 7 se sitúa, como las imágenes 5 y 6, en el espacio público: no se trata de una fiesta cívica ciudadana, sino de una conmemoración referente a la graduación de los jóvenes scouts. Así mismo, muestra la disciplinada formación en la que posan los estudiantes. En primera línea, a la izquierda, vemos a dos jóvenes, uno de los cuales lleva la bandera nacional. Todos los muchachos llevan en una mano el bordón típico. Atrás se percibe el público asistente. El espacio público sirve para disciplinar, no sólo a los jóvenes que participan del movimiento, sino también a las personas que asisten al acto y mantienen una postura ceremonial y de obediencia.

La imagen 8 muestra a los estudiantes en su espacio escolar: los jóvenes se encuentran delante del edificio de la escuela. No hay público asistente y no se trata de una conmemoración pública, sino de retratar una actividad escolar cotidiana que demuestra la inserción del escultismo en el día a día de las prácticas escolares de las escuelas agrícolas. Dejando constancia fotográfica de la actividad, se recalca la importancia que se le da a las organizaciones scouts en estas instituciones escolares. Por otro lado, para valorar la fotografía, hay que tener en cuenta que la mayor parte de las imágenes de scouts producidas durante las primeras décadas del siglo xx en Brasil se refieren más a su participación en ceremonias públicas que a sus prácticas diarias. En este caso, la excepcional reproducción fotográfica de una actividad cotidiana no se relaciona con sus actividades en el campo, sino con su función de refuerzo de la disciplina patriótica y nacionalista en las escuelas agrarias. Además, las fotografías de los boy scouts recalcan el mensaje nacionalista con elementos visuales como la presencia constante de la bandera nacional.

Mediante el análisis de las imágenes percibimos que las fotografías publicadas no sirven para hacer una crónica de la aplicación del método scout, con sus acampadas y actividades al aire libre, sino que los temas elegidos en las fotografías atendían más bien a los intereses publicitarios del poder, de la institución escolar o del grupo de escultismo que aparece en las imágenes. Su finalidad, presentando habitualmente la participación de los scouts en actividades cívicas y perfectamente formados y uniformados, era la de inculcar y difundir el discurso nacionalista y disciplinador que querían divulgar, durante 
el periodo estudiado, el gobierno e instituciones como la Liga de Defensa Nacional. ${ }^{52}$

\section{CONCLUSIONES}

Tanto en Brasil como en España la difusión del método creado por Robert Baden-Powell se difunde rápidamente y en las primeras décadas del siglo xx es asimilado por el poder y puesto al servicio de un proyecto de inculcación de los ideales nacionalistas fundamentados en el patriotismo, la disciplina y la militarización. La ductilidad del método scout permite esta instrumentalización. Para la divulgación de este discurso se utiliza abundantemente la fotografía publicada en publicaciones periódicas. Los elementos fundamentales del discurso icónico que reflejan las fotografías tanto en España como en Brasil son: la identificación de las actividades de los scouts con las autoridades civiles y militares; las manifestaciones de orden y disciplina plasmadas en formaciones y ejercicios; su presencia en actividades y conmemoraciones cívicas de carácter patriótico; y el carácter paramilitar de una uniformidad estricta, de las condecoraciones, de la presencia de banderas nacionales y del uso de bordones como eufemismo de dotación armamentística. En España, esta orientación se concreta en la organización de los Exploradores de España impulsados por la monarquía con el apoyo de las autoridades militares y de la nobleza. En Brasil aparecen distintos grupos hasta el 1924 cuando la União dos Escoteiros do Brasil consiguió aglutinar los hasta entonces independientes. El discurso nacionalista, militarista y disciplinador que traducen las fotografías de las organizaciones scouts oficiales, tanto en España como en Brasil, se pone aún más de manifiesto si advertimos la escasa información gráfica que tenemos de lo que serían las actividades propias del método scout en el campo y en la naturaleza. En las fotografías, en la prensa general, de los Exploradores de España, aparecen poco representadas o quedan muy difuminadas las actividades relacionadas con la búsqueda del progreso individual, de la socialización, del desarrollo de las habilidades personales o del compromiso con

\footnotetext{
${ }^{52}$ La Liga de Defensa Nacional fue fundada en Rio de Janeiro, en el año de 1916, por un grupo de intelectuales, entre los cuales se encontraba Olavo Bilac, mencionado anteriormente. Sobre los orígenes de la Liga de Defensa Nacional y los discursos patrióticos/nacionalistas de Bilac, véase Olavo Bilac, A defesa nacional: discursos (Rio de Janeiro: Liga de Defesa Nacional, 1917).
} 
los valores cívicos democráticos que son centrales en el método. Que la mayoría de fotografías en que aparecen de los Exploradores de España, como pasa con en Brasil, sean de actividades en el medio urbano cuando el método scout propone actividades en la naturaleza, refuerza la identificación de la organización con las estructuras del poder. Por el contrario -aunque este tema debería ser objecto de posteriores investigaciones-, la representación de estas actividades más propias del método scout en el medio natural sí aparecen en la prensa antes de la creación de los Exploradores de España cuando se quiere darlo a conocer el método. Igualmente, las fotografías mostrando acampadas, ejercicios de habilidad en el medio natural o superación de pruebas, las encontramos mucho más en las publicaciones periódicas editadas por los propios scouts. Aparecen también en las fotografías de otras organizaciones scouts españolas que se crearon fuera de la influencia de Exploradores de España, que tuvieron menor presencia en la prensa generalista pero que se han conservado en archivos y fototecas.

\section{Nota sobre los autores}

Maria Augusta Martiarena de Oliveira es doctora en Educación por la Universidade Federal de Pelotas - UFPel. Realizó estudios pós-doctorales en la Universidade do Vale do Rio dos Sinos - UNISINOS. Es docente del Instituto Federal de Educação, Ciência e Tecnologia do Rio Grande do Sul, donde actua en el Programa de Posgrado en Educación Profesional y Tecnológica. Es colaboradora del Centro de Estudos e Investigações em História da Educação (UFPel) y Grupo de Estudios en Historia de la Educación (UIB), además de integrar la directoría de la Associação Sul-Rio-Grandense de Pesquisadores em História da Educação - ASPHE.

Bernat Sureda García es Catedratico de Historia de la Educación en la Universitat de les Illes Balears. Director del Grup d'Estudis d'Història de l'Educació del Institut de Recerca e Innovació Educativa de la UIB. Director de la revista Educació $i$ Història que publica la Societat d'Història de l'Educació dels Països de la Llengua Catalana, filial del Institut d'Estudis Catalans y la UIB. Miembro del Consejo Directivo de la revista History of Education \& Children's Literature (HECL). 


\section{REFERENCIAS}

Amar, Jean-Pierre. El Fotoperiodismo. Buenos Aires: Editorial La Marca, 2005.

Annateresa Fabris (org.). Fotografia usos e funções no século XIX. São Paulo: Editora da Universidade de São Paulo, 1991.

Antipoff, Helena. "A escola e o escotismo». Revista de Educação Física, Rio de Janeiro, 25 (1935): 2-3.

Balcells Albert y Genis SAMPER. L'escoltisme català (1911-1978). Barcelona: Barcanova, 1993.

Buendía, Fabián. Los Exploradores de España. Retazos de su historia. Madrid: Imprenta Tutor, 1984.

Carvalho do Nascimento, Jorge. A escola de Baden-Powell: cultura escoteira, associação voluntária e escotismo de Estado no Brasil. Rio de Janeiro: Imago, 2008.

Cerdà, Mateu. L'escoltisme a Mallorca (1907-1995). Barcelona: Publicacions de l'Abadia de Montserrat, 1999.

Comas Francesca; Bernat Sureda. «Photography and advertising of the Maria Montessori method in Spain (1911-1931)». Paedagogica Historica 48, no. 4 (2012): 571-587.

CoRdetti, Berenice. O poder em migalhas - a escola no Rio Grande do Sul na Primeira República. Santa Maria: Universidade Federal de Santa Maria, 1997.

CoRsetTI, Berenice. «Controle e ufanismo: a escola pública no Rio Grande do Sul (1889-1930)». Revista História da Educação 2, no. 4 (1998): 57-75.

Cruz Orozco, Jose Ignacio. «Entre la Clandestinidad y la Legalidad: El Escultismo Español». En Le Scoutisme. Un Mouv ement d'Éducation Au XXème Siècle: Dimensions Internationales. Actes du Colloque International tenu à l'Université Paul Valéry, editado por Gérard Cholvy, 249-263. Montpellier: Editions Montpellier 3, 2002.

- Escultismo, Educación y Tiempo Libre. Historia del asociacionismo scout en Valencia. Valencia: Generalitat Valenciana, Institut de la Joventut, 1995.

FERnÁNDEZ-SorIA, Juan Manuel. «The presence of the British education model in Spain: reception through the Institución Libre de Enseñanza». History of Education 43, no. 1 (2014): 50-71.

FErrière, Adolphe Emmanuel. L'école active. Genéve: Edit. Du Forum, 1930.

Forestier, Marcel D. Escoltisme, ruta de llibertat. Barcelona: Suc. de Joan Gilí, 1966.

GALÍ, Alexandre. Historia de les institutions i del moviment cultural a Catalunya: 1900-1936. Llibre X: Institutions de cultura popular. Barcelona: Fundació Alexandre Galí, 1983.

García Rodríguez, María Luisa y Valeria Vittoria Aurora BosnA. «Notas históricas del Guidismo en España (1929-2009)». Historia de la Educación 30 (2011): 195-219. 
Lins, Vera. «Em revistas, o simbolismo e a virada do século». En O moderno em revistas: representações do Rio de Janeiro de 1890 a 1930, editado por Cláudia de Oliveira, 15-42. Rio de Janeiro: Garamond, 2010.

Lins, Vera. «Em revistas, o simbolismo e a virada do século». En O moderno em revistas: representações do Rio de Janeiro de 1890 a 1930, editado por Cláudia Oliveira, 175-202. Rio de Janeiro: Garamond, 2010.

LONER, Beatriz Ana. «Jornais pelotenses diários na República Velha». Ecos Revista 2, no. 1 (1998): 5-34.

López LACÁCEL, José María. Así fuimos, así somos. Historia de Scouts de España. Exploradores de España. Madrid: Federación de Asociaciones Scouts de España, 2003.

Marqués, Salom., L'escoltisme gironí. Girona: Edicions del Pel, 1984.

Martínez Navarro, Anastasio. «El escultismo en el marco de la educación física: su implantación en España». En La educación en la España contemporánea. Cuestiones históricas. Libro homenaje a Angeles Galino, editado por Julio Ruiz Berrio, 151-163. Madrid: Sociedad Española de Pedagogía, 1985.

Martins, Ana Luiza. Revistas em revista: imprensa e práticas culturais em tempos de República, São Paulo (1890-1922). São Paulo: Edusp - Editora da Universidade de São Paulo, 2001.

Montilla Salas, Xavier. «Estatutos y reglamento orgánico de la asociación nacional de los exploradores de España y disposiciones oficiales que afectan a la misma». Historia de la Educación. Revista Interuniversitaria 21-23 (20032004): 431-450.

Moreu CAlvo, Ángel C. «Idealisme naturalista dels adolescents alemanys (18471945): dels Wandervögel (ocells errants) a la Hitlerjugeng (joventut hitleriana)». Educació i Història: revista d'història de l'educació 6 (2004): 36-43.

Oliveira Nascimento, Adailson de. «Educação e civismo: movimento escoteiro em Minas Gerais (1926-1930)». Revista Brasileira de História da Educação 7 (2004): 43-73.

Perrot, Michelle. «La juventud obrera. Del taller a la fábrica». En Historia de los jóvenes. II La Edad Contemporánea, editado por Giovanni Levi y Jean-Claude Schmitt, 119-125. Madrid: Taurus, 1996.

Pimenta Velloso, Mônica. "As distintas retóricas do moderno». En O moderno em revistas: representações do Rio de Janeiro de 1890 a 1930, editado por Cláudia de Oliveira, 43-110. Rio de Janeiro: Garamond, 2010.

Pozo Andrés, María del Mar. Currículum e identidad nacional: regeneracionismos, nacionalismos y escuela pública:(1890-1939). Madrid: Biblioteca Nueva, 2000.

Quiroga Fernández de Soto, Alejandro. «Educación para la ciudadanía autoritaria. La nacionalización de los jóvenes en la dictadura de Primo de Rivera». Historia de la Educación 27 (2008): 87-104. 
SÁIz, Dolores. «Propaganda e imagen: los orígenes del fotoperiodismo». Historia y comunicación visual 4 (1999): 173-182.

SAMPER, Genis. 50 anys d'escoltisme cátala. 1927-1978. Barcelona: Fundació Jaime Bofia, Federació Catalana d'Escoltisme i Guiatge, 1992.

SANSON, Luiz de Souza R. "A Educação em tempos de nacionalismo: as representações do escotismo em Laguna-SC (1917-1960)». Dissertação Mestrado em Educação, Universidade do Estado de Santa Catarina, 2012.

SANTONI RugIU, Antonio. "Moviments, associacionisme i educació juvenil entre el vuit-cents i els primers anys del nou-cents». Educació $i$ Història: revista d'història de l'educació 6 (2003): 9-18.

SouzA. Rosa Fátima de. "A militarização da infância: Expressões do nacionalismo na cultura brasileira». Cadernos Cedes xx, no. 52 (2000):104-121.

Thоме́ Nilson. «Escotismo: história de uma prática educativa extra-escolar». En Anais do VI Congresso Luso-Brasileiro de História da Educação, 4901-4913. Uberlândia: Universidade Federal de Uberlândia, 2006.

Torrebadella Flix, Xavier. «España, regeneracionismo y deporte durante la I Guerra Mundial». Athenea Digital 16, no. 1 (2016): 237-261.

VALlory SubirÁ, Eduard y Jordi Quera. Excursionisme i escoltisme. Barcelona: Publicacions de 1'Abadía de Montserrat, 1994.

VALlory, Eduard. L'escoltisme mundial. Barcelona: Proa/Institut d'Estudis Catalans, 2010.

WARrEN, Allen. «Sir Robert Baden-Powell, the Scout Movement and Citizen Training in Great Britain, 1900-1920». The English Historical Review 101, no. 399 (1986): 376-398.

ZANON, Maria Cecilia. «A sociedade carioca da Belle Époque nas páginas do nas páginas do Fon-Fon!». Patrimônio e Memória 4, no. 2 (2007): 217-235. 